\title{
Sustainability of the Breastfeeding-Friendly Primary Care Initiative: a cross-sectional study
}

\author{
Sustentabilidade da Iniciativa "Unidade Básica Amiga da Amamentação": um estudo transversal \\ Sostenibilidad de Ia Iniciativa Unidad Primaria Amiga de la Lactancia Materna: un estudio transversal
}

'Universidade Federal Fluminense. Niterói, Rio de Janeiro, Brazil.

How to cite this article: Febrone RR, Oliveira MIC, Rito RVVF, Moraes JR. Sustainability of the Breastfeeding-Friendly Primary Care Initiative: a crosssectional study. Rev Bras Enferm. 2021;74(3):e20200869. https://doi.org/10.1590/0034-7167-2020-0869

Corresponding author:

Maria Inês Couto de Oliveira

E-mail: marinescoutoliveira@gmail.com

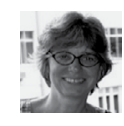

EDITOR IN CHIEF: Antonio José de Almeida Filho ASSOCIATE EDITOR: Priscilla Valladares Broca

Submission: $08-04-2020$

Approval: 02-11-2021

\begin{abstract}
Objectives: to assess the sustainability of the Breastfeeding-Friendly Primary Care Initiative by analyzing compliance with the Ten Steps in accredited units; and association with maternal satisfaction and exclusive breastfeeding. Methods: a cross-sectional study conducted in 2016. An assessment of compliance, conducted by interviews with health professionals, pregnant women, and mothers. An association between compliance and satisfaction, analyzed by Spearman s correlation test; and association between contextual/individual characteristics and exclusive breastfeeding, by the multilevel Poisson regression. Results: compliance was 5.4-10 points and satisfaction was $36.8 \%-100 \%$. Prevalence of exclusive breastfeeding was $56.7 \%$. There was a correlation between compliance and satisfaction. Higher education, prenatal orientation, hospital discharge on exclusive breastfeeding, attendance in mixed units, and female gender of the child were associated with higher prevalence of exclusive breastfeeding; on the other hand, increasing age and pacifier use were associated with lower prevalence. Conclusions: the Initiative proved to be sustainable; compliance with the Ten Steps was high and was reflected in maternal satisfaction.

Descriptors: Primary Health Care; Breast Feeding; Program Evaluation; Consumer Behavior; Cross-Sectional Studies.
\end{abstract}

\section{RESUMO}

Objetivos: avaliar a sustentabilidade da Iniciativa Unidade Básica Amiga da Amamentação pela análise do cumprimento de Dez Passos nas unidades credenciadas; e associação com satisfação materna e aleitamento materno exclusivo. Métodos: estudo transversal conduzido em 2016. Avaliação do cumprimento, realizada por entrevistas com profissionais de saúde, gestantes e mães. Associação entre cumprimento e satisfação, analisada pelo teste de correlação de Spearman; e associação entre características contextuais/individuais e aleitamento materno exclusivo, por regressão de Poisson multinível. Resultados: o cumprimento foi de 5,4-10 pontos e satisfação de $36,8 \%-100 \%$. Prevalência de aleitamento materno exclusivo foi $56,7 \%$. Houve correlação entre cumprimento e satisfação. Maior escolaridade, orientação prénatal, alta hospitalar em amamentação exclusiva, assistência em unidades mistas e sexo feminino da criança se associaram a maiores prevalências de aleitamento materno exclusivo; já idade crescente e uso de chupeta, a menores prevalências. Conclusões: A Iniciativa mostrou-se sustentável; o cumprimento dos Dez Passos foi elevado e se refletiu na satisfação materna. Descritores: Atenção Primária à Saúde; Aleitamento Materno; Avaliação de Programas e Projetos de Saúde; Satisfação do Usuário; Estudos Transversais.

\section{RESUMEN}

Objetivos: evaluar sostenibilidad de la Iniciativa Unidad Primaria Amiga de la Lactancia Materna por análisis del cumplimiento de Diez Pasos en unidades acreditadas; y asociación con satisfacción materna y lactancia materna exclusiva. Métodos: estudio transversal conducido en 2016. Evaluación del cumplimiento, realizada por entrevistas con profesionales de salud, embarazadas y madres. Asociación entre cumplimiento y satisfacción, analizada por test de correlación de Spearman; y asociación entre características contextuales/individuales y lactancia materna exclusiva, por regresión de Poisson multinivel. Resultados: el cumplimiento fue de 5,4-10 puntos y satisfacción de 36,8\%-100\%. Prevalencia de lactancia materna exclusiva fue $56,7 \%$. Hubo correlación entre cumplimiento y satisfacción. Mayor escolaridad, orientación prenatal, alta hospitalaria en lactancia materna exclusiva, asistencia en unidades mistas y sexo femenino del niño se asociaron a mayores prevalencias de lactancia materna exclusiva; ya edad creciente y uso de chupete a menores prevalencias. Conclusiones: la iniciativa se mostró sustentable; el cumplimiento de los Diez Pasos elevado y se reflejó en la satisfacción materna. Descriptores: Atención Primaria de Salud; Lactancia Materna; Evaluación de Programas y Proyectos de Salud; Comportamiento del Consumidor; Estudios Transversales. 


\section{INTRODUCTION}

Exclusive breastfeeding (EBF) in the first semester of life is recommended by the World Health Organization (WHO) ${ }^{(1)}$, because it prevents infant morbidity and mortality and diseases in the short, medium, and long term ${ }^{(2)}$.

Brazil has been an example in the promotion, protection, and support of breastfeeding, with government leadership and the active participation of civil society ${ }^{(3)}$. Policies to promote breastfeeding in Brazil have been in place since 1981, with the creation of the National Program to Encourage Breastfeeding, which ran media campaigns, established legislation to protect breastfeeding, and developed an innovative network of Human Milk Banks ${ }^{(4)}$.

It is also worth mentioning the Baby-Friendly Hospital Initiative, launched in 1991 by the WHO and the United Nations Children's Fund, recommending the Ten Steps to Successful Breastfeeding, whose compliance has been regularly monitored in Brazil through annual self-assessments conducted by the hospitals and external evaluations promoted by the Ministry of Health ${ }^{(5)}$. These policies, which have been expanded over time, have had repercussions on the practice of breastfeeding in the country ${ }^{(3)}$. In 1986, the prevalence of EBF in children under six months was $2.9 \%$, reaching $23.9 \%$ in $1996,37.1 \%$ in $2006^{(6)}$ and $47.5 \%$ in $2019^{(7)}$.

Regional public policies have also been contributing to this practice. In 1999, the Breastfeeding-Friendly Primary Care Initiative (IUBAAM) was created in the state of Rio de Janeiro, recommending Ten Steps to Successful Breastfeeding, based on a systematic review ${ }^{(8)}$. This initiative in the period 2000-2004 was supported by the Ministry of Health, which set up a team of consultants responsible for developing instructional material for training health professionals and a method for self-assessment and global evaluation of compliance with the IUBAAM's Ten Steps ${ }^{(9)}$. IUBAAM was regulated in 2005, and there were 105 accredited units in the state by 2015, more than a quarter of them in its capital ${ }^{(9)}$. The Primary Care policy in this municipality was restructured as of 2008, when the Family Health Strategy (FHS) underwent an accelerated expansion process, evolving from $3.5 \%$ to $70 \%$ of the population coverage in $2016^{(10)}$. However, these accredited units had not been re-evaluated as to whether they were maintaining compliance with IUBAAM's Ten Steps; and, over time, these practices could be deteriorating, compromising their effectiveness.

Thus, the fact that the sustainability of this policy is not known justifies this study.

\section{OBJECTIVES}

To evaluate the sustainability of IUBAAM by analyzing compliance with the Ten Steps to Successful Breastfeeding in the accredited units and its association with maternal satisfaction regarding the support received from the unit to breastfeed and exclusive breastfeeding.

\section{METHODS}

\section{Ethical aspects}

The research was approved by the Institutional Review Board of the Municipal Health Secretariat of Rio de Janeiro.

\section{Study design, period and location}

Cross-sectional observational study (according to STROBE checklist) conducted in November and December 2016, in the 26 Breastfeeding-Friendly Primary Care Units in the municipality of Rio de Janeiro, located in nine of the ten Planning Areas, which are regions of the city, defined by the City Hall, to administratively serve the neighborhoods.

\section{Sample, inclusion and exclusion criteria for assessing compliance with the Ten Steps}

To evaluate the degree of compliance with the Ten Steps and the satisfaction of pregnant women and mothers, the IUBAAM protocol was adopted ${ }^{(11)}$. The sample per unit was composed of 31 people: the manager, ten health professionals, ten pregnant women, and ten mothers, unless the unit did not have this number. The interviewees were randomly selected on the day of the evaluation. We included health professionals who had been working in maternal and child care for at least six months and pregnant women and mothers of children under 1 year old consulted at least twice in the unit.

\section{Study protocol for evaluating compliance with the Ten Steps}

The assessments were conducted in each unit on a single day by two IUBAAM evaluators accredited by the State Health Secretariat of Rio de Janeiro, assigned to a Planning Area different from their professional practice areas. The breastfeeding norms present in each unit were observed, structured questionnaires were applied to health professionals about their knowledge on breastfeeding, and users were interviewed about the orientation and support received from the unit to breastfeed ${ }^{(11)}$.

To assess compliance with the Ten Steps of the IUBAAM and satisfaction with the support received from the unit to breastfeed, standardized IUBAAM assessment instruments were used ${ }^{(11)}$. Satisfaction was measured through the question "Do you think this Primary Care Unit is supporting you to breastfeed?", with answers counted as follows: yes ( 1 point); more or less ( 0.5 point); or no (0 points). This was followed by the open question "Why?", which helped the evaluators to understand the reason for satisfaction or dissatisfaction.

The evaluation method adopted by Rito et al. ${ }^{(12)}$ was applied to assess the degree of compliance with the Ten Steps by each unit. The compliance of each Step was measured by the set of its items, ranging from 2 to 11 , and each Step was scored between 0 and 1 . The minimum final score of the unit was 0 points, and the maximum score was 10 points.

The units were categorized into three levels of compliance with the Ten Steps: superior, intermediate, and inferior, by tercile. The degree of compliance with each Step by the group of 26 units was categorized into three groups: the three best scores comprised the superior; the three worst, the inferior; and the remaining four scores, the intermediate. In each unit, we collected information on contextual characteristics: type of unit (type A: with restricted clientele, in which the entire territory is covered by the FHS; type B: mixed, which also meets free demand); number 
of health teams; location in an area of armed conflict; and time of accreditation in IUBAAM.

\section{Population, inclusion and exclusion criteria for measuring the prevalence of exclusive breastfeeding}

To measure the prevalence of EBF, a census was taken of all mothers of children under 6 months of age assisted by the unit. Babies who attended only for vaccination, those who were not accompanied by their biological mothers, second twins in cases of multiple births, and children of HIV-positive mothers were excluded. To obtain an estimate of the number of mothers to be interviewed per unit, in order to calculate the total number of questionnaires needed, the manager was asked to provide the number of children less than 6 months of age assisted in the third quarter of 2016, generating an estimate of 1,862 mothers to be interviewed.

\section{Protocol for measuring the prevalence of exclusive breastfeeding}

Based on the theoretical model of determination (Figure 1) built by the authors of this study, based on the variables identified by Boccolini et al. ${ }^{(13)}$, as associated with exclusive breastfeeding, a data collection questionnaire was prepared for mothers of children less than 6 months of age. The structured questionnaire, with closedended questions, included: name of the unit, team that assisted the child, date of interview, individual maternal characteristics (age, education, presence of partner, parity, number of prenatal visits, guidance on breastfeeding during prenatal care, study, and work) and child characteristics (gender, birth weight, type of breastfeeding at discharge from the maternity hospital, age, use of pacifier, and feeding in the last 24 hours). This questionnaire was tested in a pilot study conducted in October 2016 in two units in the accreditation process.

Contextual characteristics of the Breastfeeding-Friendly Primary Care Initiative:
- Type of Primary Health Care Unit
- Number of health teams
- Location in an armed conflict area
- Length of accreditation in the Breastfeeding-Friendly Primary Care Initiative
- Level of compliance with the Ten Steps for Successful Breastfeeding
Individual Maternal Characteristics:
- Maternal Age
- Maternal education
- Presence of partner
- Parity
- Number of prenatal visits
- Guidance about breastfeeding during prenatal care
- Mother is studying
- Mother in paid work
Children's Individual Characteristics:
- Sex of the child
- Birth weight
- Type of breastfeeding at discharge from the maternity hospital
- Child's age
- Use of pacifier

Figure 1 - Theoretical model for determining exclusive breastfeeding

The manager of each unit was asked to print, from the electronic medical records system, a list of children under 6 months per team and provide it to the nurses responsible for the teams. The nurses were selected based on their training focused on integral care and social action ${ }^{(14)}$. A previous meeting was held with the coordinators of the Health Planning Areas and with the technical heads of the nursing area of each health unit. At this meeting, the importance, objectives, and methods of the research were presented, and its participants were trained in the application of the data collection instrument. Upon returning to the respective units, the nursing technicians trained the nurses of each health team to apply the questionnaire, and there was good acceptance; none refused to participate in data collection. On the day stipulated for the beginning of the field work, the nurses started interviewing the mothers of children under 6 months of age before the appointment. If the mother did not show up for the consultation in the month of the research, the nurse would proceed to the home visit. If the mother could not be found, or refused, the nurse was instructed to fill out the questionnaire with the child's full name, gender, date of birth, age of the mother, name of the team and the unit. Those responsible for the research acted as supervisors, each unit receiving two supervisory visits: at the first week and during the last fortnight of data collection, to verify that the research protocol was being respected.

The measurement of EBF prevalence and individual maternal and child characteristics was based on data collected by nurses in interviews with mothers of children under 6 months of age assisted by the units during a one-month period. This period was defined because it is expected that, in the first semester of life, the child is followed up monthly by the unit ${ }^{(15)}$.

\section{Analysis of results and statistics}

The collected data were entered into Epi-Info 3.5.1 software and exported to SPSS 21 for descriptive analyses; and to STATA for multilevel modeling. The association between the main exposure variable "degree of compliance with the Ten Steps of IUBAAM by the unit" and the outcome "maternal satisfaction" was analyzed by scatter plot and Spearman's correlation test $\left(r_{s}\right)$ with a significance level of $5 \%{ }^{(16)}$.

Infant feeding status was classified as exclusive breastfeeding, predominant breastfeeding, complemented breastfeeding, or non-breastfeeding, based on information about the food received by the child in the last 24 hours $^{(1)}$, and the outcome was dichotomized into EBF or other status. The prevalence of EBF in children younger than 6 months of age was obtained by the ratio between the number of children aged 0 to 6 incomplete months fed exclusively with breast milk and the total number of children in this age group, multiplied by 100 .

A multilevel Poisson regression model with random intercept, with robust variance, was used to analyze the association of "contextual characteristics of the units, individual maternal and child characteristics" with the "EBF outcome". For model fitting, the gllamm command of the STATA program was used, version 11 , with the robust option to estimate robust standard errors ${ }^{(17)}$. The model adopted has two hierarchical levels, with mothers and children as first level and health units as second level. We estimated crude and adjusted prevalence ratios and calculated the respective $p$ values and $95 \%$ confidence intervals.

In the multivariate analyses, the variables whose association in the crude analysis was significant at the $20 \%$ level ( $p \leq 0.20$ ) were considered together. The variables that presented a statistically significant association with the outcome at a $5 \%$ level $(p \leq 0.05)$ were kept in the final model. 
The characteristics of the interviewed and non-interviewed mothers (losses and refusals) were compared as to maternal age, sex, and child's age using the chi-square test for homogeneity, considering a $5 \%$ significance level.

The interviews were conducted after signing a Free and Informed Consent Term. It was explained to evaluators, managers and professionals that the research was not punitive, and that no unit would be disqualified if it was not complying with the Ten Steps.

\section{RESULTS}

To assess the degree of compliance with the Ten Steps, 26 people in charge of the units, 256 health professionals, 223 pregnant women, and 219 mothers of children under 1 year of age were interviewed. The proposed number was not reached, because some small units did not have this number of professionals and customers in the period.

The degree of compliance with the Ten Steps by the units ranged from 5.4 to 10 points, with a median of 9.0. The top level of compliance ranged from 9.3 to 10 points (eight units); the middle level from 8.6 to 9.2 points (ten units); and the bottom level from 5.4 to 8.5 points (eight units).

Table 1 shows the sum of the criteria obtained in each set for each Step (the scores). The Ten Steps to Successful Breastfeeding are presented in the order in which each Step is fulfilled.

The best results were obtained for Step 2, related to team training; Step 4, about listening to pregnant women and nursing mothers; and Step 5, related to orientation on breastfeeding at birth and rooming-in - making up the top group. Four steps formed the intermediate group: Step 3, which addresses breastfeeding rights, advantages, and recommendations; Step 9, on the risks of using infant formulas, bottles, and pacifiers; Step 7, on contraceptive methods; and Step 10, on the implementation of breastfeeding support groups. In the lower group, the worst results were: Step 8 , regarding breastfeeding on demand; Step 1, regarding written policies; and Step 6, regarding breastfeeding management (Table 1).

The percentage of maternal satisfaction varied from $36.8 \%$ to $100 \%$, with a median of $90 \%$. In the higher level, the percentage was $96 \%$; in the intermediate level, $87.1 \%$; and in the lower level, $68.8 \%$. The degree of compliance with the Ten Steps was positively correlated to maternal satisfaction: the higher the degree of compliance, the higher the percentage of satisfaction $\left(r_{s}=0.680 ; p<0.001\right)$ (Figure 2).

For data collection regarding individual maternal and child characteristics, mothers of 1,846 children in the first semester of life were interviewed, ranging from 6 to 162 mothers per unit. The total number of mothers of eligible children not interviewed was 186 (9.2\%): 28 mothers refused the interview (1.4\%) and 158 did not bring their children to the routine consultation at the unit and were not found during the home visit $(7.8 \%)$. The mother's age $(p=0.103)$ and the child's sex $(p=0.745)$ were similar between interviewees and non-interviewees, but the age composition of the lost children showed a statistically significant difference from the interviewees, especially in the first and fifth month of life $(p=0.002)$. Sixteen interviews with ineligible people, such as mothers of adopted children and grandmothers, were excluded.
Table 1 - Degree of compliance with the Ten Steps by units accredited in the Breastfeeding-Friendly Primary Care Initiative, by score, Rio de Janeiro, Rio de Janeiro, Brazil, 2016

IUBAAM's Ten Steps to Successful Breastfeeding Scor

Superior group

2 Train the whole health unit team to implement the policy on breastfeeding promotion, protection and support.

4 Listen to pregnant women and mothers' concerns, living experiences and doubts about the practice of breastfeeding, supporting them, and strengthening their self-confidence.

5 Guide pregnant women about the importance of initiating breastfeeding within the first hour of birth and of rooming-in.

Intermediate Group

3 Guide pregnant women and mothers about their rights and the advantages of breastfeeding, promoting exclusive breastfeeding up to 6 months and complementary breastfeeding until 2 years or more.

9 Advise pregnant women and mothers about the risks of using infant formulas, bottles, and pacifiers, not allowing advertisements and donations of these products in the unit.

7 Guide nursing mothers about the lactational amenorrhea method and other adequate contraceptive methods to breastfeeding.

10 Implement breastfeeding support groups available to all pregnant women and mothers, searching to involve family members.

Lower Group

8 Encourage breastfeeding on demand.

1 Have a written policy on breastfeeding promotion, protection and support that should be routinely communicated to all staff in the unit.

6 Show pregnant women and mothers how to breastfeed and how to maintain breastfeeding, even if they are separated from their babies.

Note: IUBAAM - Breastfeeding-Friendly Primary Care Initiative.

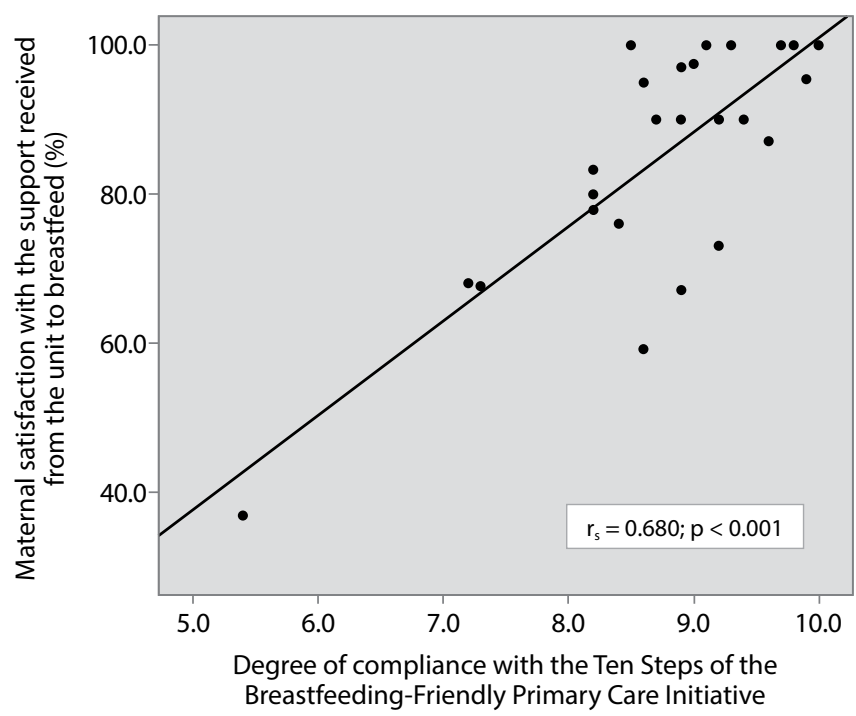

Figure 2 - Association between the degree of compliance with the Ten Steps of the Breastfeeding-Friendly Primary Care Initiative and maternal satisfaction with the support received from the unit to breastfeed, Rio de Janeiro, Rio de Janeiro, Brazil, 2016

A prevalence of EBF of $56.7 \%$ was found, ranging from $41.6 \%$ to $83.3 \%$ and a median of $57 \% .7 .1 \%$ of the children were 
predominantly breastfeeding; $24.9 \%$ were complementary breastfeeding; and $11.3 \%$ were not breastfed.

In the crude analysis, the following contextual variables were associated with EBF: type of unit, number of teams, and time of accreditation in IUBAAM. Location in an area of armed conflict and the degree of compliance with the Ten Steps had no statistically significant association with EBF. The individual maternal characteristics associated with exclusive breastfeeding were: higher education; presence of a partner; attendance to six or more prenatal visits; receiving guidance on breastfeeding during prenatal care; and the woman not studying or on maternity leave from study and work. Female child, adequate birth weight, and discharge from the maternity hospital in exclusive or complemented breastfeeding were the individual child characteristics associated with a higher prevalence of EBF. Increasing age of the child in months and the use of pacifiers were associated with a lower prevalence of EBF (Table 2).

In the multivariate analysis, the following were associated with exclusive breastfeeding: child monitored in a type $B$ unit; higher maternal education; guidance on breastfeeding in the prenatal period; female child; and exclusive or complementary breastfeeding at discharge from the maternity hospital. The increasing age of the child and the use of pacifiers were associated with lower prevalence of the outcome (Table 3).

\section{DISCUSSION}

In this study, conducted only with units accredited in the IUBAAM, a high degree of compliance with all the Steps was verified, with a small variation from 0.80 to 0.95 and with certain homogeneity in the performance of the units, evidencing the sustainability of this Initiative. Children assisted by longer accredited units showed a higher prevalence of exclusive breastfeeding, although this association was not maintained in the multivariate analysis. The median degree of compliance with the Ten Steps was higher than that found (5.6) in 2007 by Rito et al. ${ }^{(12)}$ in a representative sample of 56 units in the same city, among which only two were accredited.
Table 2 - Prevalence and crude prevalence ratio of exclusive breastfeeding in Breastfeeding-Friendly Primary Care Units according to contextual characteristics of the units as well as individual maternal and infant characteristics, Rio de Janeiro, Rio de Janeiro, Brazil, 2016

\begin{tabular}{|c|c|c|c|c|c|}
\hline & $\mathbf{N}$ & $\%$ & EBF (\%) & CPR & $p$ \\
\hline \multicolumn{6}{|l|}{ Contextual characteristics } \\
\hline Type of Primary Health Care Unit & & & & & \\
\hline $\begin{array}{l}\text { Type A - Assigned clientele } \\
\text { Type B - Mixed clientele }\end{array}$ & $\begin{array}{c}1.552 \\
294\end{array}$ & $\begin{array}{l}84.1 \\
15.9\end{array}$ & $\begin{array}{l}54.3 \\
69.0\end{array}$ & $\begin{array}{c}1 \\
1.273\end{array}$ & 0.002 \\
\hline \multicolumn{6}{|l|}{ Number of Health Care Teams } \\
\hline 1 to 4 & 578 & 31.3 & 63.5 & 1 & \\
\hline 5 to 7 & 1268 & 68.7 & 53.5 & 0.842 & 0.013 \\
\hline \multicolumn{6}{|l|}{ Location in an area of armed conflict } \\
\hline No & 1.292 & 70.0 & 56.5 & 1 & \\
\hline Yes & 554 & 30.0 & 56.9 & 0.997 & 0.963 \\
\hline \multicolumn{6}{|l|}{ IUBAAM accreditation time } \\
\hline 1 to 5 years & 1.421 & 77.0 & 54.4 & 1 & \\
\hline 6 years or more & 425 & 23.0 & 64.0 & 1.174 & 0.049 \\
\hline \multicolumn{6}{|l|}{$\begin{array}{l}\text { Degree of Compliance with IUBAAM's Ten Steps to } \\
\text { Successful Breastfeeding }\end{array}$} \\
\hline 5.4 to 8.5 & 401 & 21.7 & 60.1 & 1 & \\
\hline 8.6 to 9.2 & 767 & 41.5 & 58.3 & 0.977 & 0.801 \\
\hline 9.3 to 10 & 678 & 36.7 & 52.7 & 0.883 & 0.215 \\
\hline \multicolumn{6}{|l|}{ Individual characteristics } \\
\hline \multicolumn{6}{|l|}{ Maternal age } \\
\hline Adolescent & 347 & 18.8 & 54.2 & 1 & \\
\hline Adult & 1.499 & 81.2 & 57.2 & 1.053 & 0.357 \\
\hline \multicolumn{6}{|l|}{ Maternal education } \\
\hline Incomplete elementary school & 394 & 21.3 & 57.5 & 1 & \\
\hline Complete elementary school or higher & 1.452 & 78.7 & 53.3 & 1.083 & 0.087 \\
\hline \multicolumn{6}{|l|}{ Presence of a partner } \\
\hline No & 296 & 16.0 & 51.7 & 1 & \\
\hline Yes & 1.550 & 84.0 & 57.5 & 1.112 & 0.136 \\
\hline \multicolumn{6}{|l|}{ Parity } \\
\hline Primimarous & 833 & 45.1 & 57.1 & 1 & \\
\hline Multiparous & 1.013 & 54.9 & 56.2 & 0.987 & 0.801 \\
\hline \multicolumn{6}{|l|}{ Number of prenatal visits } \\
\hline$<5$ & 125 & 6.8 & 49.6 & 1 & \\
\hline 6 or more & 1.721 & 93.2 & 57.1 & 1.148 & 0.194 \\
\hline \multicolumn{6}{|l|}{ Guidance on breastfeeding in the prenatal period } \\
\hline No & 234 & 12.7 & 49.6 & 1 & \\
\hline Yes & 1.609 & 87.2 & 57.6 & 1.187 & 0.026 \\
\hline \multicolumn{6}{|l|}{ Mother studies } \\
\hline Studying & 95 & 5.1 & 51.6 & 1 & \\
\hline On leave or does not study & 1.751 & 94.9 & 56.9 & 1.107 & 0.196 \\
\hline \multicolumn{6}{|l|}{ Mother in paid work } \\
\hline Working & 456 & 24.7 & 46.9 & 1 & \\
\hline Not Working & 1.138 & 61.6 & 58.8 & 1.250 & $<0.001$ \\
\hline On maternity leave & 251 & 13.6 & 64.5 & 1.367 & $<0.001$ \\
\hline \multicolumn{6}{|l|}{ Baby's sex } \\
\hline Male & 890 & 48.2 & 54.2 & 1 & \\
\hline Female & 956 & 51.8 & 58.9 & 1.085 & 0.081 \\
\hline Birth weight & & & & & \\
\hline Low weight & 141 & 7.6 & 45.4 & 1 & \\
\hline Adequate weight & 1.704 & 92.3 & 57.6 & 1.263 & 0.032 \\
\hline Type of breastfeeding at discharge from the ma & & & & & \\
\hline Not breastfed & 41 & 2.2 & 17.1 & 1 & \\
\hline Was breastfed and received complement & 253 & 13.7 & 37.9 & 2.237 & 0.018 \\
\hline Exclusively breastfed & 1.551 & 84.0 & 60.7 & 3.560 & $<0.001$ \\
\hline Baby's age (in months) & & & & & \\
\hline 0 & 290 & 15.7 & 86.2 & 1 & \\
\hline 1 & 275 & 14.9 & 70.2 & 0.814 & 0.002 \\
\hline 2 & 313 & 17.0 & 67.1 & 0.778 & $<0.001$ \\
\hline 3 & 320 & 17.3 & 57.8 & 0.671 & $<0.001$ \\
\hline 4 & 334 & 18.1 & 36.5 & 0.424 & $<0.001$ \\
\hline 5 & 314 & 17.0 & 27.1 & 0.314 & $<0.001$ \\
\hline Use of a pacifier & & & & & \\
\hline No & & 60.5 & 72.0 & 1 & \\
\hline Yes & 727 & 39.4 & 28.0 & 0.596 & $<0.001$ \\
\hline
\end{tabular}


Table 3 - Adjusted prevalence ratio of exclusive breastfeeding among children up to 6 months assisted by Breastfeeding-Friendly Primary Care Units, Rio de Janeiro, Rio de Janeiro, Brazil, 2016

\begin{tabular}{|c|c|c|c|}
\hline Variables & aPR & $(95 \%) \mathrm{Cl}$ & $p$ \\
\hline \multicolumn{4}{|l|}{ Type of Primary Health Care Unit } \\
\hline Type A - Assigned clientele & 1 & & \\
\hline Type B - Mixed clientele & 1.154 & $1.028-1.296$ & 0.015 \\
\hline \multicolumn{4}{|l|}{ Maternal education } \\
\hline Incomplete elementary school & 1 & & \\
\hline Complete elementary school or higher & 1.096 & $1.017-1.182$ & 0.017 \\
\hline \multicolumn{4}{|l|}{$\begin{array}{l}\text { Guidance on breastfeeding in the prenatal } \\
\text { period }\end{array}$} \\
\hline No & 1 & & \\
\hline Yes & 1.228 & $1.074-1.405$ & 0.003 \\
\hline \multicolumn{4}{|l|}{ Baby's sex } \\
\hline Male & 1 & & \\
\hline Female & 1.076 & $1.022-1.133$ & 0.005 \\
\hline \multicolumn{4}{|l|}{$\begin{array}{l}\text { Type of breastfeeding at discharge from the } \\
\text { maternity hospital }\end{array}$} \\
\hline Not breasfed & 1 & & \\
\hline $\begin{array}{l}\text { Was breastfed and received } \\
\text { complement }\end{array}$ & 1.924 & $1.024-3.616$ & 0.042 \\
\hline Exclusively breastfed & 2.995 & $1.634-5.491$ & $<0.001$ \\
\hline \multicolumn{4}{|l|}{ Baby's age } \\
\hline Increasing age in months & 0.824 & $0.800-0.850$ & $<0.001$ \\
\hline \multicolumn{4}{|l|}{ Use of a pacifier } \\
\hline No & & & \\
\hline Yes & 0.691 & $0.633-0.754$ & $<0.001$ \\
\hline
\end{tabular}

Unlike what was verified by Rito et al. ${ }^{(12)}$, Step 2, related to team training, was the one that achieved the highest score. The commitment of the Rio de Janeiro Municipal Health Secretariat in the training of professionals in IUBAAM seems to be one of the pillars for the sustainability of this initiative, despite the period of political and economic crisis, which threatens the principles of the Unified Health System ${ }^{(18)}$, and the staff turnover resulting from the model of Social Health Organizations adopted in this municipality ${ }^{(19)}$. Step 4 also showed a high degree of compliance: mothers' appreciation of listening and strengthening their selfconfidence in breastfeeding indicates that this guidance has been provided within the counseling paradigm ${ }^{(4,20)}$.

In this investigation, an increasing gradient was found between the degree of compliance and the average percentage of maternal satisfaction, so pregnant women and mothers seem to be able to accurately distinguish the unit's support for breastfeeding and were not afraid to express their opinion to evaluators outside the unit. The proportion of pregnant women and mothers satisfied with the support received from the unit for breastfeeding was high, with a median of $90 \%$, but its variation among units was large. The degree of compliance with the Ten Steps of IUBAAM showed a positive and statistically significant correlation with this outcome. Consistently, Oliveira et al. ${ }^{(11)}$ also found a wide variation in maternal satisfaction among studied units and a strong correlation between this outcome and the practice of the Ten Steps.

The EBF was practiced by more than half of the children less than 6 months of age assisted by the units. This prevalence is good according toWHO parameters ${ }^{(2)}$ and was higher than in surveys conducted in the county, with an upward temporal trend, from $13.8 \%$ in 1996 to $23.3 \%$ in $2003^{(22)}$ and $40.7 \%$ in $2008^{(23)}$. It also surpassed the one observed in the evaluation research on the implementation of the Ten Steps of IUBAAM in the municipality in $2007(47.6 \%)^{(24)}$. This increase was consistent with the intensification of breastfeeding promotion in the country and the implementation of IUBAAM in the municipality of Rio de Janeiro since $2003^{(22)}$. The degree of compliance with the Ten Steps was not statistically significantly associated with $E B F$, a result that differed from that observed by Oliveira et al. ${ }^{(8)}$ and by Rito et al. ${ }^{(24)}$. In this study, all units evaluated were accredited in IUBAAM, and the relative homogeneity in the degree of compliance with the Ten Steps seems to have led this outcome to be more influenced by other variables.

The only contextual variable that was associated with EBF was the child's follow-up in a type B unit, whose prevalence of the outcome was $15 \%$ higher than the follow-up in units where the territory is covered by the FHT. This result corroborates that obtained by Rito et al. ${ }^{(24)}$, in which the prevalence was $10 \%$ higher. Type B units also have family health teams and have more stable civil servants, while the turnover in the FHT makes personnel training more difficult, which may have had an impact on this outcome.

Higher maternal education was associated with an almost $10 \%$ higher prevalence of EBF, similar to what was found in 2008 in the II Brazilian Capitals Breastfeeding Prevalence Survey ${ }^{(23)}$; and in a systematic review on factors associated with EBF in the first six months of life in Brazil ${ }^{(13)}$. Socioeconomic gradients generally reproduce themselves in health gradients, so processes of social exclusion may explain the lower prevalence of exclusive breastfeeding found among less educated mothers. This direction of association, however, was not consistent in other settings, such as Saudi Arabia, where mothers with no university education showed higher prevalence of exclusive breastfeeding ${ }^{(25)}$.

The prevalence of EBF was $23 \%$ higher for pregnant women who received guidance on breastfeeding during prenatal care, as observed by Pereira et al. ${ }^{(26)}$ and Pellegrinelli et al. ${ }^{(27)}$. Step 6, concerning the guidance that pregnant women and mothers should receive on breastfeeding management, obtained the lowest score of compliance in this evaluation, however, it should be reinforced. Prenatal care is essential for breastfeeding, since breastfeeding counseling during pregnancy can increase selfefficacy and prevent breastfeeding problems $\mathrm{s}^{(20)}$.

The child being exclusively breastfed at discharge from the maternity hospital was the variable that most increased the prevalence of EBF. Baptista et al. ${ }^{(28)}$, in Curitiba, Pereira et al. ${ }^{(26)}$ and Alves et al. ${ }^{(29)}$, in Rio de Janeiro, also found this association, which reaffirms the importance of working together to promote, protect and support breastfeeding in Primary Care and in maternity hospitals.

Female children had higher EBF practice. The II Brazilian Capitals Breastfeeding Prevalence Survey ${ }^{(23)}$ pointed in the same direction. This higher prevalence may have a cultural origin, such as the belief present in many parts of Brazil that boys need more nutritional intake from foods other than breast milk ${ }^{(13)}$. National survey in India showed inverse association: female children being less exclusively breastfed than male children ${ }^{(30)}$.

The increasing age of the child in months was significantly associated with a lower prevalence of $E B F$, because as the child grows, the likelihood of receiving other foods increases. With each month of life, EBF decreased by $18 \%$, similar to that found in Rio de Janeiro by Pereira et al.(26), in Brazil by the II Brazilian Capitals Breastfeeding Prevalence Survey ${ }^{(23)}$ and also in other contexts, such as in India ${ }^{(30)}$. 
The use of pacifiers was the factor that showed the strongest inverse association with the practice of EBF, as pointed out in systematic reviews ${ }^{(13,31)}$. The habit of offering a pacifier to babies can reduce the frequency and effectiveness of breast feedings, because, for a breast feeding to be effective, the baby needs to open its mouth wide, position the tongue under the areolar region of the breast and milk the breast milk by sucking slowly and deeply, while the use of a pacifier requires a superficial sucking with minimum effort ${ }^{(31)}$. However, future studies exploring this association are needed, since a meta-analysis based on two studies (experimental and quasi-experimental) found no association between restricted use of pacifiers by healthy infants of mothers motivated to breastfeed and exclusive breastfeeding at 3 and 4 months of age ${ }^{(32)}$.

\section{Study limitations}

Cross-sectional studies may present limitations by collecting data on exposure and outcome at a single point in time, making it difficult to establish a temporal relationship between the events. Memory bias may have occurred because data on previous events were collected. Another limitation was the maternal refusal to be interviewed and the loss of children under 6 months old, which may have generated selection bias. These losses occurred despite the nurses' efforts to interview the mothers before the appointment or through active search during home visits.

Although the percentage of losses was less than $10 \%$ overall, there were units where this percentage reached $18 \%$. However, this does not seem to have been a differential bias, because the maternal age and sex of the child were similar between the interviewed and non-interviewed group. The age of the children differed because, throughout the field research, listed children turned 6 months old, and their mothers were not interviewed; while others were born, and their mothers were, even though they were not listed by the units at the beginning of data collection, which translated into a higher proportion of younger children interviewed.

\section{Contributions to the field of nursing or public health policy}

Finally, it is worth considering that evaluating policies for the promotion, protection, and support of breastfeeding, as recommended by the $\mathrm{WHO}$, is essential to know the current situation regarding the validity of their content over time, the facilitating factors, and the barriers encountered between the initial plan and the implementation of actions. It is important to analyze the repercussion between the activities developed and the health of the population by means of health indicators ${ }^{(33)}$, as the prevalence of exclusive breastfeeding in the first semester of life, especially in the vulnerable population of low-income children, mostly assisted by these units. This study shows that the active and effective participation of nurses in the field stage was fundamental.

The nurse's attributions in Primary Care include the supervision, coordination, and development of continuing education activities for nursing technicians and community health workers, as well as the integration with other professionals ${ }^{(14)}$. The process involved in the collection of data on the clientele and the type of breastfeeding practiced provides for reflection and the construction of a care plan under the responsibility of the primary health care units, configuring a relevant contribution for the nursing area, as well as for the nursing care as a whole.

It is recommended that the Breastfeeding-Friendly Primary Care Initiative monitor compliance with the Ten Steps and maternal satisfaction, which can be done by self-assessment or by the performance of external evaluators, with the support of the Health Secretariats involved. This constant evaluation, which should include the participation of nurses, will contribute to maintaining the quality of actions for the promotion, protection, and support of breastfeeding in Primary Health Care.

\section{CONCLUSIONS}

It was concluded that the degree of compliance with the IUBAAM's Ten Steps by the accredited units was high, indicating the sustainability of actions to promote, protect, and support breastfeeding, even with the passage of time and changes in the hiring system that increased staff turnover. The EBF outcome did not change significantly with the degree of compliance with the Ten Steps, and individual maternal and infant characteristics had greater explanatory power on exclusive breastfeeding. Pregnant women and mothers accurately distinguished the breastfeeding support received from the units, leading the unit's performance in meeting the Ten Steps to be reflected in maternal satisfaction.

\section{REFERENCES}

1. World Health Organization. Indicators for assessing infant and young child feeding practices: conclusions of a consensus meeting held 6-8 November 2007 in Washington D.C., USA. Geneva: World Health Organization [Internet]. 2008 [cited 2020 Jul 03]. Available from: http:// www.who.int/iris/handle/10665/43895

2. Victora CG, Bahl R, Barros AJD, França GVA, Horton S, Krasevec J, et al. Breastfeeding in the 21st Century: epidemiology, mechanisms and lifelong effect. Lancet. 2016;387:475-90. https://dx.doi.org/10.1016/ S0140-6736(15)01024-7

3. Rollins NC, Bhandari N, Hajeebhoy N, Horton S, Lutter CK, Martines JC et al. Why invest, and what it will take to improve breastfeeding practices? Lancet. 2016;387(10.017):491-504. https://doi.org/10.1016/S0140-6736(15)01044-2

4. Hernandez AR, Victora CG. Biopolíticas do aleitamento materno: uma análise dos movimentos global e local e suas articulações com os discursos do desenvolvimento social. Cad Saúde Pública. 2018;34(9):1-12. https://doi.org/10.1590/0102-311x00155117

5. Araújo RG, Fonseca VN, Oliveira MIC, Ramos EG. External evaluation and self-monitoring of the Baby-friendly Hospital Initiative maternity hospitals in Brazil. Int Breastfeed J. 2019;14:1. https://doi.org/10.1186/s13006-018-0195-4 
6. Boccolini CS, Boccolini PMM, Monteiro FR, Venâncio SI, Giugliani ERJ. Breastfeeding indicators trends in Brazil for three decades. Rev Saúde Pública. 2017;51(108):1-9. https://doi.org/10.11606/s1518-8787.2017051000029

7. Universidade Federal do Rio de Janeiro. Estudo Nacional de Alimentação e Nutrição Infantil -ENANI-2019: Resultados preliminares Indicadores de aleitamento materno no Brasil [Internet]. UFRJ: Rio de Janeiro, 2020[cited 2020 Jul 03]. 9 p. Available from: https://enani. nutricao.ufrj.br/index.php/relatorios/

8. Oliveira MIC, Camacho LAB, Souza IEO. Promoção, proteção e apoio à amamentação na Atenção Primária à Saúde no Estado do Rio de Janeiro, Brasil: uma política da saúde pública baseada em evidência. Cad Saúde Pública. 2005;21(6):1.901-10. https://doi.org/10.1590/ S0102-311X2005000600040

9. Oliveira MIC, Rito RVVF, Barbosa GP. Unidade Básica Amiga da Amamentação. In: Carvalho MR, (Coord.). Amamentação: Bases científicas. 4.ed. Rio de Janeiro: Guanabara Koogan; 2017. p. 485-491

10. Secretaria Municipal de Saúde do Rio de Janeiro. Evolução da cobertura de atenção primária. Rio de Janeiro [Internet]. 2018 [citado 2020 Jul 28]. Available from: http://www.rio.rj.gov.br/web/sms/exibeconteudo?id=5494688

11. Oliveira MIC, Camacho LAB, Tedstone AE. A method for the evaluation of primary health care units' practice in the promotion, protection and support of breastfeeding: results from the State of Rio de Janeiro, Brazil. J Hum Lact. 2003;19(4):365-73. https://doi. org/10.1177/0890334403258138

12. Rito RVVF, Castro IRR, Trajano AJB, Gomes MASM, Bernal RTI. Breastfeeding-Friendly Primary Care Initiative: degree of implementation in a Brazilian metropolis. Rev Nutr Campinas. 2013;26(4):385-95. https://doi.org/10.1590/S1415-52732013000400001

13. Boccolini CS, Carvalho ML, Oliveira MIC. Factors associated with exclusive breastfeeding in the first six months of life in Brazil: a systematic review. Rev Saúde Pública. 2015;49(91):1-15. https://doi.org/10.1590/S0034-8910.2015049005971

14. Ferreira SRS, Périco LAD, Dias VRGF. The complexity of the work of nurses in Primary Health Care. Rev Bras Enferm [Internet]. 2018;71(Supl 1):704-9. https://doi.org/10.1590/0034-7167-2017-0471

15. Ministério da Saúde (BR). Secretaria de Atenção à Saúde. Departamento de Atenção Básica. Saúde da criança: crescimento e desenvolvimento. Brasília: Ministério da Saúde [Internet]. 2012 [cited 2020 Jul 03]. Available from: http://bvsms.saude.gov.br/bvs/ publicacoes/saude_crianca_crescimento_desenvolvimento.pdf

16. Siegel S, Castellan NJ. Estatística não-paramétrica para ciências do comportamento. 2.ed. Porto Alegre: Artmed; 2006.448 p.

17. Rabe-Hesketh S, Skrondal A. Multilevel and Longitudinal Modeling Using Stata. 2.ed. Texas: STATA Press Publication 2008. 384 p.

18. Caldas JMP, Santos ZMSA. Health and equity [Editorial]. Rev Esc Enferm USP. 2016;50(4)542-3. https://doi.org/10.1590/ S0080-623420160000500001

19. Governo do Estado do Rio de Janeiro. Decreto $n^{\circ} .43 .261$, de 27 de outubro de 2011. Regulamenta a Lei no 6.043 , de 19 de setembro de 2011. Dispõe sobre a qualificação de entidades sem fins lucrativos como Organizações Sociais, no âmbito da saúde, disciplina a celebração de contratos de gestão com tais entidades e dá outras providencias[Internet]. 2011 [cited 2020 Jul 28]. Available from: http://www.silep. planejamento.rj.gov.br/decreto_43_261_-_271011.htm

20. Shafaei FS, Mirghafourvand M, Havizari S. The effect of prenatal counseling on breastfeeding self-efficacy and frequency of breastfeeding problems in mothers with previous unsuccessful breastfeeding: a randomized controlled clinical trial. BMC Women's Health. 2020;20(1):94. https://doi.org/10.1186/s12905-020-00947-1

21. World Health Organization (WHO). Infant and Young Child Feeding: a tool for assessing national practices, policies and programmes. Genebra:World Health Organization [Internet]. 2003 [cited 2020 Jul 28]. Available from: http://www.who.int/iris/handle/10665/42794

22. Castro IRR, Engstrom EM, Cardoso LO, Damião JJ, Rito RVFV, Gomes MASM. Time trend in breast-feeding in the city of Rio de Janeiro, Southeastern Brazil: 1996-2006. Rev Saúde Pública. 2009;43(6):1-8. https://doi.org/10.1590/S0034-89102009005000079

23. Ministério da Saúde (BR). Secretaria de Atenção à Saúde. Departamento de Ações Programáticas e Estratégicas. II Pesquisa de Prevalência de Aleitamento Materno nas Capitais Brasileiras e Distrito Federal[Internet]. 2009 [cited 2020 Jul 28]. Available from: http://bvsms.saude. gov.br/bvs/publicacoes/pesquisa_prevalencia_aleitamento_materno.pdf

24. Rito RVVF, Oliveira MIC, Brito AS. Degree of compliance with the ten steps of the Breastfeeding Friendly Primary Care Initiative and its association with the prevalence of exclusive breastfeeding. J Pediatr (Rio J). 2013;89(5):477-84. https://doi.org/10.1016/j.jped.2013.02.018

25. Hegazi MA, Allebdi M, Almohammadi M, Alnafie A, Al-Hazmi L, Alyoubi S. Factors associated with exclusive breastfeeding in relation to knowledge, attitude and practice of breastfeeding mothers in Rabigh community, Western Saudi Arabia. World J Pediatr. 2019;15(6):601-9. https://doi.org/10.1007/s12519-019-00275-x

26. Pereira RSV, Oliveira MIC, Andrade CLT, Brito AS. Fatores associados ao aleitamento materno exclusivo: o papel do cuidado na Atenção Básica. Cad Saúde Pública. 2010;26(12):2.343-54. https://doi.org/10.1590/S0102-311X2010001200013

27. Pellegrinelli ALR, Pereira SCL, Ribeiro IP, Santos LC. Influência do uso de chupeta e mamadeira no aleitamento materno exclusivo entre mães atendidas em um Banco de Leite Humano. Rev Nutr Campinas. 2015;28(6):631-9. https://doi.org/10.1590/1415-52732015000600006

28. Baptista GH, Andrade AHHKG, Giolo SR. Fatores associados à duração do aleitamento materno em crianças de famílias de baixa renda da região sul da cidade de Curitiba, Paraná, Brasil. Cad Saúde Pública. 2009;25(3):596-604. https://doi.org/10.1590/S0102-311X2009000300014

29. Alves JS, Oliveira MIC, Rito RVVF. Guidance on breastfeeding in primary health care and the association with exclusive breastfeeding. Cienc Saúde Coletiva. 2018;23(4):1077-88. https://dx.doi.org/10.1590/1413-81232018234.10752016 
30. Ogbo FA, Dhami MV, Awosemo AO, Olusanya BO, Olusanya J, Osuagwu UL et al. Regional prevalence and determinants of exclusive breastfeeding in India. Int Breastfeed J. 2019;14:20. https://doi.org/10.1186/s13006-019-0214-0

31. Buccini GDS, Pérez-Escamilla R, Paulino LM, Araújo CL, Venancio SI. Pacifier use and interruption of exclusive breastfeeding: Systematic review and meta-analysis. Matern Child Nutr. 2017;13(3). https://doi.org/ 10.1111/mcn.12384

32. Jaafar SH, Ho JJ, Jahanfar S, Angolkar M. Effect of restricted pacifier use in breastfeeding term infants for increasing duration of breastfeeding. Cochrane Database Syst Rev. 2016;(8):CD007202. https://doi.org/10.1002/14651858.CD007202.pub4.

33. Brousselle A, Champagne F, Contandriopoulos AP, Hartz Z (Org.). Avaliação: conceitos e métodos. Rio de Janeiro: Editora Fiocruz; 2011.292 p. 